\title{
Quase Poesia Quase Química
}

JoÃo C. PAIVA*

\section{Eu não sou poeta!}

Mas sou poeta porque todos somos poetas.

Se me perguntarem porque escrevo poesia responderei pronto, como respondo a algumas perguntas de química: não sei mas vou querer saber...

Nos versos escorre algo que a caneta diz por mim, que não conheço bem, que desejo exprimir mas não saberia como sem esse caldo de letras no papel.

A química e a poesia são mundos diferentes mas já mereceram ensaios geniais, como os de Rómulo de Carvalho, que nos inspira...

Tenho a oportunidade de publicar em formato de e-book uma coletânea de trinta e quatro poemas intitulados "quase poesia quase química", que estará disponível on line em www.spq.publicacoes/poesia e em www.poesia.jcpaiva.net. A edição digital tem vantagens de acessibilidade e ecologia que me atraem.

Agradeço à Sociedade Portuguesa de Química o apoio desta publicação, no âmbito do seu centésimo centenário.

Agradeço ainda as preciosas sugestões de vários colegas, em particular os exercícios escritos abaixo, dos amigos Víctor Gil, Raquel Gonçalves-Maia e Graça Miguel.

Se um só dos versos, que por mim alguém escreve, tocasse um coração, fascinasse para a química e encantasse para a química da vida um sopro de brisa, isso seria para mim uma dádiva.

\footnotetext{
* Centro de Investigação em Química, Departamento de Química e Bioquímica, Faculdade de Ciências, Universidade do Porto

Rua do Campo Alegre, 687, 4169-007 Porto

E-mail: jcpaiva@fc.up.pt
}

\section{Alguns Poemas da Coletânea}

\section{Dose certa}

\section{Procuro a}

minha dose.

Quanto sou?

Que espaço ocupo?

Que tempo tomo?

Às vezes, sou demais, quase veneno.

Encho com excessivas palavras.

Melhor fora ser

silencioso solvente.

Outras vezes

devia ser mais presente.

Mais soluto.

Mais concentrado.

Sou micro-escala

quando deveria

gritar ao mundo

toda a injustiça.

Meu sonho?

Ser tónico, não tóxico.

Procuro a

minha dose,

a dose certa..

\section{Eletrão}

Tantas voltas

quânticas

sem saber

nunca

onde estás?

(como eu).

Se te agarram

deixas de dar-te

a conhecer

(como eu).
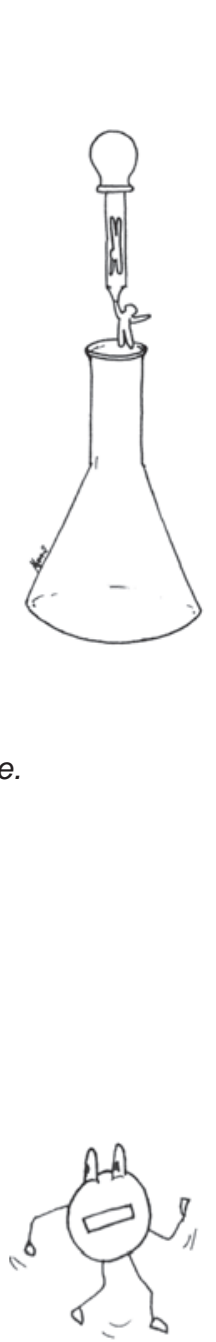

Se te olham

ficas rubro

e deixas de ser

o que eras

(como eu).

Precisas de muitos

iguais para

te significar

(como eu).

Com teus pares

podes dar

luz

como eu...

Alquimia

De tempos

antigos

à noite

ou de dia

caverna escondida

segredo,

alquimia.

Entre ferro

e engenho

um qualquer

vil metal,

sai o sonho

tamanho,

pedra

filosofal.

Sai ouro

e mistério,

receitas

à sorte

elixir

milagroso,

corte eterno

da morte...

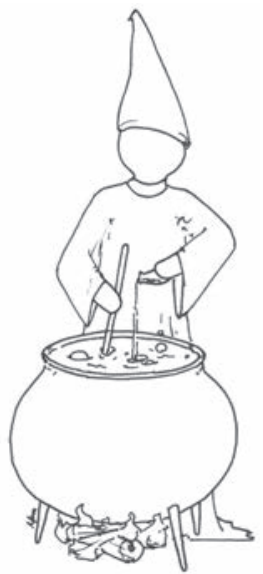




\section{Recomeço}

Cresce desordem, desinformação.

Perdido,

então,

sustido,

parado

na segunda lei.

No equilíbrio,

bem sei,

a energia livre

não varia.

E o tempo anda

até um dia.

E eu espero

e desespero.

E o acaso?

Haverá sorte?

A dúvida

não é morte.

Morrer

é entropia

congelada.

E a vida,

agitada,

quem diria,

é incerta

mas aberta

à alegria.

\section{OPINIÕES}

O uso de "quase" neste título, repetido embora não como um "quase-quase", poderia, à partida, ter pelo menos duas leituras. Uma seria uma declaração de humildade do autor, quer face à criação poética, quer ao saber e à criação científica. A outra seria a promessa de uma mistura homogénea - ou, mesmo, de uma combinação - fecunda entre Química e Poesia, em que, numa imaginativa fertilização cruzada, as partes se diluem no todo.

É a segunda interpretação que, fundamentalmente, eu perfilho, porventura temperada com uma pitada da primeira: alguma modéstia quanto se trata de ter (mais) um químico reconhecido a "pentear a foice por seara alheia". Por fertilização cruzada entendo, aqui, a importância da Poesia na comunica- ção da Ciência, assim como - o principal objetivo desta obra, creio - o uso da Ciência na construção da emoção estética, designadamente, através da metáfora.

Como despretenciosamente escrito noutro lugar (Poesia \& Ciência: implicações para a educação formal e não formal em Ciência, Victor M.S. Gil e M. Cristina Pinheiro, coleção Ciência \& Ca , Exploratório Ciência Viva, 2011), podem identificar-se diversos tipos de cruzamentos da Poesia com a Ciência, desde os que são centrados na história, natureza e papel da Ciência, até à relação com áreas científicas específicas (Física, Química, Biologia, ...). Nestes casos temos normalmente a exploração da Ciência, com a sua linguagem própria, em prol do poema, quer como analogia - ou, mesmo, metáfora -, quer tirando partido de palavras com duplo sentido na vida e na Ciência, quer, simplesmente, apresentando Ciência em formato próprio da Poesia - com mera dimensão descritiva - ou, no extremo oposto, integrando verdadeiramente o registo científico na agenda poética com mais valia: emoção, protesto, mensagem, testemunho e reflexão.

É possível encontrar exemplos de todas estas intersecções nos poemas em análise, intencionalmente com títulos que têm origem na Química - vocábulos e expressões da Química (Carbonos, Eletrão, Densidade, Mesmo DNA, Hidrogénio, Tabela Periódica, Espectro, Reação, Titulada, Reduzido...) - e outros com ela relacionados (Na Dose Certa, Eu e a Química, Ironia ao Natural, ...). A principal exceção é o último que coloca lado a lado as duas manifestações da criatividade humana em causa: "Ciência ou Poesia".

- Em "Na dose certa", há termos de duplo sentido, como "concentrado" e há a metáfora do tóxico e do tónico na procura da dose certa a favor da relação com o outro e em prol da justiça.

- Em "Eu e a Química”, explora-se a analogia entre a Química, ciência das "coisas próprias" e das suas transformações, e a essência do autor que deseja valer pelo que faz e transforma no mundo à sua volta e em si mesmo.
- Em "Carbonos", encontra-se sobretudo uma descrição esquemática, em formato poético, com abundante utilização de nomes de espécies químicas e uma alusão (para muitos enigmática, as 4 patas) à tetravalência do carbono, elemento central e vital, nas diversas situações em que ocorre (daí o plural "carbonos").

- Em "Decaimento", a referência ao decaimento radioativo, à meia-vida e à radiação, faz ponte com os que já passaram ao mundo da memória mas ainda nos influenciam, para deixar a mensagem de que há um sentido escondido da vida compatível com o aleatório.

- Em “A Química em b por v", a paródia à pronúncia do norte mostra que a Química se pode revelar a todos: o que é preciso é que se veja bem ...ou "beja vem".

- Em “A Química e a pressa”, explora-se uma analogia com a Cinética Química (catalisar, mecanismo, ativação, barreira) para deixar uma mensagem de que a pressa é o pecado do mundo atual, não deixando espaço para amar, contemplar, confiar ... escorregar feliz.

- Em "Densidade", pode falar-se de uma metáfora entre objeto denso - mais centrado em si mesmo - e egocentrismo - ambos afundam num protesto contra o egoísmo.

- Em "Carbono-lição", uma analogia entre a Química do carbono, com as suas ligações variadas, e a importância das nossas interações com os outros, ainda que diversas e de diferentes durações.

- Em "Alquimia", uma descrição ritmada dos sonhos secretos dos alquimistas (pedra filosofal, elixir da longa vida).

- Em "Enxofre", uma descrição ritmada de um pouco da Química do enxofre (chuvas ácidas, ...) com um breve toque final quase romântico (penteado e ligações de enxofre).

- Em "Mesmo DNA", um breve convite à fraternidade.

- Em "Solução", palavra de duplo sentido, aquecer em cadinho é a metáfora para procurar a compreensão do mundo, quando, afinal, só se encontra o caminho e não a solução.

- Em "Hélio", a metáfora das ligações frágeis e ocasionais, de pouco comprometimento, tal como os átomos de hélio. 
- Em "Segunda lei", a desordem em Física e na vida não é incompatível com a ordem e a harmonia.

- Em "Ironia ao que é natural", uma breve mensagem educativa: nem tudo o que é natural é bom, nem tudo o que não é natural é mau. Ironia: a aspirina, o perfume, o plástico de uma válvula cardíaca.

- Em “Oxigénio", átomos que já pertenceram a outros seres humanos, como convite à união entre seres humanos.

- Em "Da Química", "Recomeço", "Transformação", "Cor", "Hidrogénio", descrições químicas com analogias.

- Em "Sal da terra", a metáfora do autor como sal que tempera e se confunde em solução.

- Em "Cálculos de amor", a mensagem de que dividir amor é ... multiplicar.

- Em "Laboratório químico", uma descrição das operações em laboratório em formato poético que exigem atenção e ... emoção.

- Em "Cobre", uma descrição ritmada com fim humorístico.

- Em "Tabela Periódica", uma descrição ritmada de uma tabela que resume o mundo.

- Em "Titulada", uma descrição química como base de uma subtil metáfora: sabendo titulante, sabe-se titulado.

- Em "Futeboleno", a descrição ritmada de uma curiosa substância recente.

- Em "Reduzido", uma descrição de transferência de eletrões em analogia com dar e receber.

- Em "Espectro", essencialmente uma descrição ritmada da origem dos espectros, sendo que o melhor espectro de gente é ... o sorriso.

- Em "Hino à Química”, um anagrama com adjetivação da Química, exceto na ironia do último verso: Alquimia.

- Em "Reação", outra vez a ideia de que o poeta deseja transformar-se, como em Química, para ser melhor.

- Em "Ciência ou Poesia", um dilema em que rigor é associado a uma e emoção a outra.

Temos, assim, variadas mensagens fortes avançadas pelo autor a favor da transformação própria para se ser melhor, de que há um sentido da vida (apesar dos caos), de que a compreensão é apenas um caminho, da relação fraternal com os outros, da atuação individual, como o sal que tempera, da necessidade de pausa para se ser feliz, ...

Tudo isto, várias vezes através da analogia e, mesmo, da metáfora, sempre que a analogia surge como imperativo estético.

O humor também não está ausente, aflorando em vários exemplos.

Frequentes são aspetos da Química tratados em formato ritmado próprio de poema, em que a dimensão é essencialmente descritiva.

Numa nota menos positiva, não posso deixar de reconhecer algumas passagens menos conseguidas, em minha opinião, designadamente por não lhes encontrar suficiente dimensão poética. Mas pode ser falta minha ...

Finalmente, a escolha de "Ciência ou Poesia" para último poema é certamente acertada, reconhecendo-se o prazer na cultura de ambas, embora se me afigure que há alguma simplificação em identificar Ciência com rigor e Poesia com emoção. Por um lado, há prazer mas há, também, trabalho. Por outro, há quem defenda que "a emoção estética é comum à descoberta científica e à criação artística: admira primeiro, compreenderás depois" (G. Bachelard). No entanto, embora tratando-se, em ambos os casos, de uma aventura intelectual de raiz abstrata, em que a imaginação e a criatividade desempenham o papel central, de mãos dadas com a emoção, pode contrastar-se a perenidade da obra poética (e da obra artística, em geral) com a precariedade de muitas construções científicas ao longo dos tempos.

Mesmo a terminar, um comentário sobre a personalidade do autor enquanto se manifesta nestas obras. Aqui se reconhecem declaradas e conhecidas preocupações de natureza social, ética e filosófica. Mas não deixa de ser curioso que a exuberância com que, habitualmente, converte uma ideia que considere interessante em ação seja ela de natureza prática ou de co- municação com terceiros - dá lugar, nestes poemas, a uma abordagem estilizada, quase esquemática. Um mecanismo de compensação face a "encho com excessivas palavras" do primeiro poema "Na dose certa"?

Victor Gil

Exploratório Infante D. Henrique

São vários os caminhos para se chegar - e se fazer chegar - à Química. E variados os caminhos que conduzem à sua integração na cultura universal. João Paiva escolheu a "quase poesia" para nos transportar até à "quase química". E fê-lo com a simplicidade que é exigida por um apuramento de estilo tão caro à Ciência quanto à Poesia.

O primeiro poema, Dose certa, revela-nos desde logo o autor, as suas potencialidades e preocupações. A dose que se move entre o tempo e o espaço, as palavras e o silêncio, a presença e a ausência, a dose que grita contra as injustiças do mundo é metaforicamente interpretada pelas relações soluto-solvente, tónico-tóxico, micro- e macro-escala.

Apreciei Carbono, delirante, vital, quase animal; admirei Mesmo DNA e a sua urgência de fraternidade; contemplei a magia de Solução e o seu bonito jogo de palavras onde a Química (tal como a Poesia) saem consolidadas; sorri à Ironia ao natural, colorida e enganadora como um demónio; li e reli, com fascínio, Futeboleno.

Mais oferece o autor, que nos alimenta e se alimenta destas metamorfoses de escrita. Leva no bolso, ele assim o diz, Ciência e Poesia. E, em fórmulas de luz, numa embrulha a outra com sedução e mestria.

Uma palavra ainda para as ilustrações, tão singelas e virtuosas quanto elucidativas, a correlacionarem-se muito bem com a textura poética.

\section{Raquel Gonçalves-Maia} Universidade de Lisboa

"Quase Poesia Quase Química", de João Paiva, é um conjunto de poemas que glorificam a Poesia da Química e, enquanto poesia, constituem uma permanente interrogação sobre o próprio Homem e o seu contexto cósmico. 
A dualidade reflexão-resistência, conhecimento-palavra, mente-matéria, homem-molécula, encontra-se em permanente voo, sereno ou impetuoso, no excelentíssimo trabalho e expressão de célebres cientistas, químicos e professores, como António Gedeão e Roald Hoffmann.

Se, por um lado, e homenageando os cem anos da Sociedade Portuguesa de Química e de seus fazedores, esta coletânea pode ser encarada como uma inspiração pedagógica, num encontro alternativo com o aluno e num simultâneo apelo à criatividade e imaginação, por outro, a busca do ensinador vai mais além.

Num impulso mais extenso, o autor evoca-nos a questão paradoxal da infinita essencialidade e da existencialidade-limite, numa profusa ligação en- tre química e eu íntimo. Esta intimidade e beleza parecem, em grande parte, nascer desta inequívoca aliança.

Sem austeridade formal, estes poemas testemunham a fidelidade do poeta a algumas preocupações permanentes: certeza e incerteza; o quântico e o infinitamente grande; espaço e tempo; o caos e a harmonia; o visível e o invisível; emotividade e a sua contenção.

E assim, o poeta-químico, homem-molécula, no seu questionamento, transfigura-se em eletrão, em metal, em transformação, em entropia, em dissolução.

Poder-se-á dizer que no seu conjunto esta poética revela um certo estado de rutura de estruturas cristalinas... ("The Metamict State", R. H.) na sua interpelação consciente, desamparada, e perturbante.

Perceciona-se ainda na sua densidade reflexiva, uma mutação continuada, tangencialmente intransponível, englobante da ciência, da palavra escrita, da humanidade, da religião. Contudo, se o desamparo intersticial é claro, o autor parece encontrar o seu contrário na esperança ... vinda ... da ciência? do cósmico? da crença?

Como o poema incorpora não apenas o próprio poeta, na sua condição humana e universal, mas essencialmente o leitor, é a ele que convidamos a interrogar-se, a conhecer-se, através do infinitamente pequeno, dos átomos e das moléculas.

Maria da Graça Miguel

Universidade de Coimbra

\section{Atualidade Científica}

\section{Uma Nova Classe de Superbases}

Investigadores dos EUA descobrem que as ciclopropeniminas podem ser usadas como "superbases" altamente eficazes em processos de organocatálise enantioselectiva (J. Am. Chem. Soc., DOI: 10.1021/ja3015764). Estes resultados poderão conduzir ao desenvolvimento mais rápido e fácil de novos compostos quirais com aplicações farmacêuticas, entre outras.

Recentemente, foram desenvolvidos diversos tipos de bases orgânicas para a catálise enantioselectiva de reações de transferência de protões para a obtenção de produtos opticamente ativos. O trabalho focou-se essencialmente nas amidinas e guanidinas quirais.

No entanto, estes compostos apresentam uma basicidade limitada e baixo poder catalítico. Agora, Jeffrey S. Bandar e o professor Tristan H. Lambert da Columbia University demonstram que os compostos 2,3-bis(dialquilamino)ciclopropeniminas, caracterizados por elevada basicidade, revelam-se como organocatalisadores quirais de eficácia muito superior.

Os iões ciclopropénio, formas protonadas das bases catalíticas, correspondem a aromáticos estabilizados por ressonância, que tornam as ciclopropeniminas altamente básicas. Assim, a basicidade das ciclopropeniminas é 3,5 ordens de magnitude mais elevada do que as guanidinas comparáveis, catalisando as reações com velocidades até 800 vezes superiores.

Bandar e Lambert usam uma diciclohexil-ciclopropenimina num procedimento à escala preparativa para catalisar uma adição de Michael, obtendo $25 \mathrm{~g}$ de produto com uma enantioselectividade de $99 \%$.

Assim, reportam a síntese do catalisador a partir de matérias-primas baratas e acessíveis, a obtenção de uma estrutura de Raios $X$ da versão protonada, e a proposta de um mecanismo para a reação catalisada.

Choon-Hong Tan da National University of Singapore afirma que os novos catalisadores "são fáceis de produzir e o seu scale-up é possível, para além das condições reacionais serem relativamente suaves". Acrescenta ainda que "a sua alta basicidade deve possibilitar a catálise de uma vasta gama de reações, nomeadamente as que produzem componentes farmacêuticos quirais ativos".

Por outro lado, Henk Hiemstra da University of Amsterdam questiona se os catalisadores funcionarão tão bem para outras reações. Todavia, frisa a sua admiração pela facilidade com que os catalisadores são sintetizados e pelo seu manifesto bom desempenho. Assim, afirma que "a descoberta pode levar à continuação de um considerável trabalho de pesquisa em torno deste tipo de catalisadores".

(adaptado do artigo de 02/04/2012 de Stu Borman: New Class of Superbases, Chemical \& Engineering News - http://cen.acs.org/articles/90/i14/New-Class-Superbases.html)

Paulo Brito (paulo@ipb.pt) Instituto Politécnico de Bragança 